\title{
The importance of tourism contributions in Egyptian economy
}

\author{
Ahmed K Elnagar \\ Assistant Professor at the Department of Administrative and Financial Sciences and Techniques, Community \\ College, Taibah University, Saudi Arabia; Suez Canal University, Egypt \\ ahmed_karam@tourism.suez.edu.eg
}

\begin{abstract}
Abdelkader Derbali
Assistant Professor at the Department of Administrative and Financial Sciences and Techniques, Community College, Taibah University, Saudi Arabia. Department of Management Sciences, Higher Institute of Informatics and Management of Kairouan, Kairouan University, Tunisia

derbaliabdelkader@outlook.fr
\end{abstract}

DOI: https://doi.org/10.31559/IJHTS2020.1.1.5

\begin{abstract}
:
Tourism in Egypt is one of the most important sources of national income, with the annual dollar revenues it provides, and the foreign currency returns that enabled it to participate significantly in the gross domestic product, and to combat unemployment by employing a wide segment of the workforce in Egypt. Egypt is one of the most prominent tourist countries in the world, with its number of tourists arriving in the world, and it is distinguished by the abundance of tourist attractions of all kinds, the spread of temples, museums, monuments, historical and artistic buildings and vast gardens on its land, and its possession of strong infrastructure based on serving the tourism sector, including Hotel rooms, villages, tourist resorts, tourism companies and airline offices. In this paper, we present an overview of tourism in Egypt and its impact on the Egyptian economy based on a data published by the World Tourism Organization (2019) and by the Egyptian Ministry of Tourism and Antiquities, 2017. We indicate the types of tourism in Egypt. We present the factors which have an impact on tourism in Egypt. Finally, we present the contribution of tourism in Egyptian economy. From our analysis, it has been shown that tourism is one of the most important fields in Egypt and indeed in all countries around the world, but tourism in Egypt is characterized by many factors, as Egypt abounds in many recreational and tourist places, and there is also religious tourism because Egypt has many religious places.
\end{abstract}

\section{Key words: Tourism; economic growth; Egypt; Contributions}

\section{Introduction}

The phenomenon of tourism in Egypt developed during the ancient times, and the ancient Egyptians practiced many recreational activities, and they related to sport tourism in its various forms, intellectuals and clerics took an interest in cultural tourism, and Nile tourism spread throughout the country, and a large number of foreign regions came to Egypt with the aim of medical tourism, as well The movement of travel and travel was active between the different regions of Egypt, and the archaeological plates recorded international relations between Egypt on the one hand and ancient Syria on the other hand, during which they exchanged visits that had all the characteristics of tourism with their modern meaning (Shaalan, 2005; Ragab, 2014; Haiying, 2019; Brida et al., 2020).

During the Middle Ages, Egypt witnessed the most prosperous periods of tourism as a result of the activity of travel and the expansion of the circle of Arab trips after the emergence and spread of Islam and the extension of the Islamic state between the Indian subcontinent, North Africa and southern Europe. Cairo was one of the most important cultural and cultural centers in the Islamic state and one of the wealthiest, like several Islamic capitals. Others, and its palaces, gardens and libraries were among the attractions that attracted large numbers of tourists. Economic boom and security and desire for knowledge contributed to the popularity of tourism and the activity of trips and their multiplicity in Egypt during that period. Egypt's tourist significance has increased since the end of the eighteenth century and during the nineteenth century, due to several factors, including the French campaign that restored communication between the Egyptian and his ancient civilization through the scholars accompanying the campaign who studied the Egyptian civilization and revealed many valuable monuments, and presented Egypt 
to the West Through literature she talks about, such as the book Describing Egypt, which led to her popularity and draws the attention of European countries (Shaalan, 2005; El Gohary, 2012; Smith, 2014; Haiying, 2019; Brida et al., 2020; Salah Eli Din, 2020).

Also, with the arrival of Muhammad Ali to the rule of Egypt, interest in the tourism movement returned, so he established in 1845 the Traffic Authority to oversee the land route to India and the business of tourists, postal and goods, and relied on it to oversee the rest of the desert, horses, carts, and food for tourists, and to organize traffic on the road between Cairo and the cities of Suez and Alexandria put telegraph towers to inform on the arrival and construction of cruise ships and tourist groups, and hotels equipped to accommodate tourists were accommodated. Abbas's first era witnessed a special interest in tourism and providing the necessary facilities for the movements of tourists, so the Cairo / Suez road was paved with stones, and the first regulation on the regulation of residence of foreigners and tourists was laid in Egypt in May 1849 (Aziz, 1995; Shaalan, 2005).

In addition, Saeed Pasha also followed the path of his predecessors and issued in March 1857 the Said Regulation that organized Matters related to tourists from their arrival in Egypt during their stay to their departure. Foreigners flocked to Egypt during the era of Khedive Ismail, whether for work or tourism, and helped in the flow of tourism to Egypt during that period, its participation in international exhibitions, and taking advantage of the occasion of the opening of the Suez Canal for international navigation to propagate tourism to Egypt (Aziz, 1995; Shaalan, 2005; Avraham, 2016; Salah Eli Din, 2020).

Then, the images of Arab cooperation in the tourism field started with the spread of bilateral tourism agreements between a large number of Arab countries, after which it turned into a multi-lateral cooperation within the framework of the League of Arab States, and the Arab countries held more than 40 environmental tourism agreements to support and encourage Arab tourism. It was also subject to renewal and development, and the largest number of tourism agreements came from Egypt, which held 11 bilateral agreements with various Arab countries, and the most important provisions of those agreements are to exchange tourism experiences, information, statistics, training and rehabilitation, in addition to Single tourist laws and regulations, and lay the foundations for common services and tourist facilities and the preservation of the environment and heritage, and to simplify procedures for the movement of tourists. To support tourism development efforts within the framework of the League of Arab States, the Arab Ministerial Council for Tourism was established in 1997 and the Arab Tourism Organization in 2006. In October 2015, Egypt was elected as the head of the Executive Office of the headquarters of the World Tourism Organization in Colombia (Brida et al., 2020; Salah Eli Din, 2020).

In this study, we try to present an overview of tourism in Egypt and its effect on the economy. We specify the types of tourism in Egypt. We indicate the main factors that affect tourism in Egypt. Finally, we present the contribution of tourism in Egyptian economy. It has been revealed that tourism is one of the greatest vital fields in Egypt and certainly in all countries around the world, but tourism in Egypt is categorized by numerous issues, as Egypt thrives in numerous recreational and tourist places, and there is also religious tourism because Egypt has many religious places.

This paper is organized as follow; we present in section 2 the types of tourism in Egypt. In section 3, we present the crisis which have an impact on the tourism sector in Egypt. Section 4 present the contribution of tourism on Egyptian economy. Finally, section 5 concludes.

\section{Types of tourism in Egypt}

In this section, we present all types of tourism in Egypt. There are 8 types of tourism destination in Egypt.

\subsection{Recreational tourism}

The recreational tourism in Egypt attracts a large number of tourists from all over the world, due to Egypt's distinguished beaches with a length of more than $3000 \mathrm{~km}$ on the coasts of Bahrain, white and red, which tourists spend their vacation in what is known as beach tourism. Among the tourist attractions in the first place are Sharm El Sheikh, Dahab, Nuweiba, Taba, South Sinai Governorate, Hurghada, Safaga, Marsa Alam, Red Sea Governorate, Ain Sukhna City, Suez Governorate, and these areas are famous for clear waters, colorful coral reefs, rare fish, and the widespread practice of marine sports such as diving and snorkeling.

As well as the establishment of camps and beach camps between the beach and the mountains or camps and mountain trips and spread by the tourist resorts that operate throughout the year. The city of El Alamein in the North Coast region, which overlooks the Mediterranean Sea, also emerges as a promising tourist region due to its multiple tourist villages along the seacoast. As for Nile tourism, it also attracts a remarkable number of tourists and captures their interest, and Nile cruises and evening nights in the tourist ships along the Nile River constitute an important tourist attraction, as several Nile ships and floating hotels cross the Nile River from Cairo to Luxor and Aswan and vice versa through all cities Upper Egypt, overlooking the river, and has private berths in each city to see its important landmarks separately (El Gohary, 2012; Avraham, 2016; Haiying, 2019). 


\subsection{Cultural tourism}

The cultural tourism in Egypt is one of the most important factors of tourist attraction, as it represents the most important and oldest types of tourism, and the pharaonic, Greek and Roman antiquities available in Egypt have made entire cities open museums and contributed to the emergence of Egyptian museums of international standing, and archaeological and nomadic missions have come to Egypt without interruption, The authors and the authors were fascinated and inspired by hundreds of books in different languages (El Gohary, 2012; Avraham, 2016).

Among the most important cultural and archaeological tourist areas in Egypt are the Pyramids of Giza, the Sphinx, Saqqara, the Dahshur region in Giza, the Roman theater, Roman baths, the temples of Cape Verde, Caesarean, the Pillar of the As-Sawar and Qaitbay Citadel in Alexandria. As for the city of Luxor, it is an open museum, which includes one third of all monuments of the world, the most famous of which are the Karnak Temple, Luxor Temple, Valley of the Kings, Valley of the Queens and Monastery of the City. Aswan, besides, it is a wintering place for tourists to warm its weather in the winter season, includes several historical monuments such as the temples of Abu Simbel, the island of Philae and the island of plants.

Upper Egypt in general includes several historical monuments such as the Dandara Temple in Qena and the Medioun area in Beni Suef and Tel el-Amarna in Minya and the pyramids of Lahun and Hawara and Qarun Palace in Fayoum. As for the Lower Egypt, it includes the Wadget Temple, Tel Al-Faraeen, Desouk, Medina of Fouh, and the ancient Saa Al-Hajar area in Passion and Wadi Ad-Natrun monasteries. In Sinai, areas such as Jabal Musa and St. Catherine Monastery. In the Western Desert, there are separate areas such as the Hibis Temples, Quwaita, and Rayyan in Kharga, the Mott Cemeteries, the Gourmet Village, the Balat Village, and the Palace Village in Dakhla, as well as the city of Paris, the Farafra Palace, and the marine oases (El Gohary, 2012; Avraham, 2016; Haiying, 2019; Brida et al., 2020).

The museums are also spread in almost every governorate of Egypt and vary between national, artistic, and regional museums, and almost every museum specializes in displaying monuments of a particular era or era, such as the Egyptian Museum, the Museum of Islamic Art, the Museum of Modern Egyptian Art, the Palace of Jawhara, the Manial Palace, the Greco-Roman Museum and the Museum. Nubia, the Museum of Fine Arts, the Coptic Museum, the Agricultural Museum, the Military Museum, the El Alamein Military Museum and the Sunken Museum, in addition to the huge museums that are still under construction such as the Grand Egyptian Museum in the Pyramids desert and the Civilization Museum in Fustat, which will represent a qualitative and cultural shift Great for the history of Egypt and its cultural heritage and archaeological as well, including Sadmanh of a number of alarming artifacts and methods of museum presentation and the coefficient of modern restoration (Shaalan, 2005; El Gohary, 2012; Haiying, 2019).

\subsection{Eco-tourism}

Egypt has several rare environmental sites that attract visitors wishing to know their natural and wild components. Natural reserves in Egypt are subject to the supervision of the Ministry of Environment, and their visits will be on guided tours using recreational means of transportation, boat rides or walking according to the region. Among the most famous of these are the Ras Muhammad Reserve and the Nabq Reserve in Sharm El-Sheikh, St. Catherine Reserve, Jabal Elba Reserve in Halayeb, Taba Reserve It embraces the colorful valley, the Dean's Matruh Reserve, the Abu Gallum Reserve in Dahab, Lake Qarun Reserve and the Wadi Al-Rayan Reserve in Fayoum, in which the Whale Valley is one of the World Heritage sites in Egypt, and includes the first museum of its kind in the Middle East for fossils and climate change, and guest breaks. Aquatic museums are also landmarking of coastal cities, such as the Alexandria Aquarium (Shaalan, 2005; Avraham, 2016).

\subsection{Medical Tourism}

The presence of hot springs and springs with mineral and sulfur water in Egypt varies in depth, capacity and temperature, and its water contains several mineral salts and some minerals of therapeutic value such as sodium carbonate, magnesium and iron, and laboratory measurements also showed the suitability of salinity in these natural water resources for purposes Hospitalization.

This is in addition to the enjoyment of the hospital areas from a dry climate, moderation in temperature and humidity, and the sand and silt they contain, which are suitable for hospitalization from several diseases, such as rheumatic and dermatological diseases, bone diseases, the digestive system, respiratory system, and the spread of herbs and medicinal plants on its soil from which drugs, vegetable and aromatic oils are extracted. There are many areas that enjoy the advantage of medical tourism in Egypt, such as: Helwan, Ain Al-Sirah, Ain Al-Sokhna, Hurghada, Fayoum and the oases of Western Sahara, Wadi al-Natrun, Aswan, Safaga and Sinai (El Gohary, 2012).

\subsection{Sports tourism}

The sports tourism in Egypt is one of the important means of promoting and attracting tourism, and Egypt has a strong infrastructure in several sports such as football, handball, volleyball, squash, equestrian, golf, marine sports and hunting, bowling, which qualified them to host several international and continental championships, Attracted many visitors from different countries to attend its activities and enjoy watching their athletes and their sports 
teams, so Egypt hosted the African Nations Cup for Soccer in 1959, 1974, 1986, 2006, and hosted the African Men's Handball Championship five times, most recently in 2016, while it won in November 2015.

The right to host a championship A world of handball for men in 2021, and won the right to organize the African Nations Volleyball Cup for Men in 2015, and was assigned to organize the World Volleyball Championship for youth under 23 men and scheduled for 2017, and Egypt organizes the Egypt International Marathon in Luxor, and the Pharaohs Rally which It starts from the northern coast to the Pyramids of Giza, and the International Pyramid Squash Championship, and it succeeded in organizing the World Squash Championship for the first time in December 2015 (Haiying, 2019; Brida et al., 2020).

\subsection{Festival tourism}

The Egypt holds several festivals that have a popular turnout from home and abroad, with the intention of achieving several goals, including tourism promotion and diversification of vocabulary of attractions, and encouraging shopping activities, and sponsoring artistic events. Abu Simbel, the annual celebration of the discovery of Tutankhamun's tomb in Luxor, the Cairo International Folk Song Festival, the Cairo International Film Festival, the Alexandria International Film Festival, the International Documentary Film Festival, the Ismailia Folklore Festival, the Cairo Festival International Experimental Theater, Cairo Festival for Arab Media, the International Festival of the International Equestrian Festival and the fulfillment of the Nile, fishing festival in Port Said, the festival (El Gohary, 2012).

\subsection{Conference tourism}

The conference and the exhibition tourism represent an important tourist pattern in Egypt because of its distinguished geographical location and political standing that enabled it to host tens of international conferences annually in the political, economic, cultural, medical and professional fields. The holding of those conferences is concentrated in Cairo, Alexandria, Sharm El-Sheikh, Hurghada, and Ismailia, because these cities have international conference centers that have technical and technological capabilities and modern equipment of audio devices and simultaneous translation in various languages that made them a desirable kiss by international conference organizers. Organizing and hosting conferences and exhibitions in Egypt.

Egypt succeeded in organizing several successful international conferences such as the Conference on Supporting and Development of the Egyptian Economy, the Cairo International Book Fair, and hosting many international conferences, including the first international tourism exchange on behalf of the Mediterranean Stock Exchange, the first international conference for the Mediterranean for businesswomen, the conference of the Federation of Tourism Companies and Organizations of the American Countries Latin "Kotal", conference of the General Union of Italian Travel Agents and Tourist Companies "ViaFit". Two years ago, she won the Emax Exhibition 2012 in Germany for "incentives and conferences" tourism (Haiying, 2019; Brida et al., 2020).

\subsection{Religious tourism}

Egypt abounds in many sacred religious places, whether Jewish, Christian or Islamic, to which hundreds of visitors come in what is known as religious tourism, and it is spread throughout its monuments and sanctuaries of the three monotheistic religions, including historical Islamic monuments such as the Hussein Mosque, Ibn Tulun Mosque and Al-Azhar Mosque, and many buildings and castles that register Islamic history of Egypt, including the Citadel of Saladin in Cairo, the Qait Bey Citadel in Alexandria, and the Nakhal Fort in Sinai.

Likewise, the ancient Christian sites that record the path of the Holy Family, such as the Church of Saint Sergius, to which the Holy Family took refuge in Egypt, the Hanging Church, the Monastery of St. Catherine, the Monastery of St. Anthony, the founder of the Order, the Monastery of St. Paul in the Red Sea, the Monastery of Dronka in Assiut, and many other monasteries and other ancient churches. Also, on its land are several sites of Jewish religious significance, such as Jabal Musa in Sinai, the Synagogue of Ben Ezra, the Shaari Shmaim synagogue in Cairo, the Eliyahu Hanbey synagogue, and the Eliyahu Hazan synagogue in Alexandria (Shaalan, 2005; El Gohary, 2012; Haiying, 2019).

\section{Crises and negative influences}

\subsection{The impact of terrorist incidents}

The security threats have had a continuous impact on the Egyptian tourism sector over the past twenty years (Farouk, 2014; Smith, 2014). Where 58 foreign tourists were killed in the 1997 accident in Luxor, while the Sinai accident killed 32 people, most of them foreigners in 2004, and the Cairo accident in 2005 killed and injured a number of foreign tourists in central Cairo, and the Sharm el-Sheikh accident in 2005 killed 88 people, most of them Egyptians, as the 2006 Dahab incident claimed the lives of 23 people, most of them Egyptians, and in 2015 Mexican tourists fell victim to a wrongful attack by the Egyptian security forces during their incursion into a restricted area believed to be a terrorist group, unlike the war launched by the Egyptian security forces on terrorism in the Sinai, and news that Reported by local and foreign media. 
The victims and the other between the two sides. These successive incidents caused huge losses in the Egyptian tourism sector due to the warning of foreign embassies and victims' countries from traveling to Egypt at those times and inviting its tourists to Egypt to return to their country (Aziz, 1995; Drakos and Kutan, 2003; Dana, 2017; Helene, 2017).

\subsection{The impact of political events}

The successive political events that began with the January 25 revolution and were interrupted by attacks on foreign journalists such as British Natasha Smith and South African Lara Logan in Tahrir Square in Cairo and then the June 30 events that were followed by attacks on vital state installations, had a noticeable impact on Egypt's tourism sector negatively. As the number of tourists declined during the January 25 revolution by more than $37 \%$ that year, down from 14.7 million in 2010 to only 8.8 million at the end of 2011, which affected a wide range of businesses directly or indirectly dependent on tourism, from hospitality services Accommodation, transportation, travel and excursions (Egyptian Ministry of Tourism and Antiquities, 2017).

In 2013, Egypt ranked 85th among the countries of the world in the field of tourism and travel, down from the 75th position it occupied in 2011. By the end of the first part of 2014, the number of tourists decreased again by $25 \%$ compared to the same time in 2013, and the revenues of the tourism sector decreased $25 \%$, too. However, it moved back slightly in 2015, ranking 83.

\subsection{The impact of road accidents}

The problem of road accidents in Egypt is one of the biggest obstacles to tourist attraction, as the increase in human losses in Egyptian citizens and foreign tourists as a result of exposure to road accidents caused a decrease in the percentage of foreign tourist turnout in Egypt, due to the great human suffering it caused to accident victims and their families, as well as the harmful impact On public and private property, insurance amounts and compensation.

The number of road accidents that occurred between January 1990 and October 2008 was about 426.4 thousand accidents, which resulted in the death of about 100.9 thousand people, and injury to approximately 440 thousand injured. While the death rate due to car accidents in Egypt is 222 deaths per 1,000 km of roads, compared to the global average that ranges between 4 to 20 deaths. The cost of these accidents is estimated at about 16 billion pounds annually (Haiying, 2019).

\subsection{The impact of aviation accidents}

The aviation accidents in Egypt over the past years have raised a state of caution and anticipation among tourists from traveling to Egypt. The most prominent of these incidents is represented in the accident of the Egyptian Airlines Flash 604 flight in 2004 when a Boeing 737 Classic plane collided with the waters of the Red Sea shortly after taking off from Sharm El-Sheikh International Airport, killing all those on board and Among them are a large number of foreign tourists. The Luxor tourist balloon crash, which occurred in 2013, is the worst recorded accident in the history of flying balloons, resulting in the deaths of 19 people, all of them foreign tourists.

The flight 9268, which occurred in October 2015 of a Russian Airbus A321 plane on its way from Sharm ElSheikh to St. Petersburg, had a great impact on the Egyptian tourism sector, especially in the Sinai region, where it led to the reluctance of Russian tourists to visit Egypt who were representing The vast majority of Sharm El-Sheikh resorts harmed the city's economy, which relies mainly on tourism. Flight accident 804, which occurred in May 2016 for an Egyptian plane inside the Egyptian airspace while it was arriving from Paris Charles de Gaulle Airport in France to Cairo Airport with 66 passengers on board (Egyptian Ministry of Tourism and Antiquities, 2017; Haiying, 2019).

\subsection{The impact of the global financial crisis}

Since September 2008, the global economy began to face an exceptional financial crisis, which resulted in a state of global economic stagnation, which started from the United States and then moved to Europe and the developed world, and was the least affected by the least developed countries, including Egypt. In line with the decline in the global tourism movement that was affected by the financial crisis, the demand for tourism in Egypt experienced a significant decline during that period, which negatively affected the numbers of international tourists and the number of nights in the Egyptian tourism sector and led to a slowdown in the tourist movement during the intensification of the crisis (Egyptian Ministry of Tourism and Antiquities, 2017; Haiying, 2019).

\section{The contribution of tourism to the Egyptian economy}

The tourism is a great income for the state, and tourism is of great importance because it has a very great historical value through which people get to know ancient Egyptian ages, and the field of tourism provides many job opportunities so it helps to get rid of the problem of unemployment, and tourism is a historical destination And a large civilization, as the importance of tourism in Egypt and its types are many (Shaalan, 2005; Egyptian Ministry of Tourism and Antiquities, 2017; Brida et al., 2020). 
The tourism is one of the most important sources of income for any country, which is that the guide introduces tourists to the tourist attractions in his country, and also knows the history and civilization of his country for tourists, and many know the illiteracy of tourism in Egypt and its types greatly, in addition to that there is internal tourism external tourism (Brida et al., 2020).

The importance of tourism in Egypt and its types is many, as there are many types of tourism, including religious tourism, which is going to religious places, and cultural tourism, which means going to places that have cultural relics. Recreational tourism, which is a visit to recreational places, and sports tourism is a visit to clubs where soccer or tennis and handball are played, therapeutic tourism is the places where there are places that treat the body and remove pain from it and search for the importance of tourism in Egypt as a source of national income talking about this in a simple way (Shaalan, 2005; El Gohary, 2012; Brida et al., 2020).

In this section, we present the contribution of tourism in Egyptian economy. We use a recent data published by the Egyptian Ministry of Tourism and Antiquities (2017) and by the World Tourism Organization (2019). These contributions are measured by the Total number of tourists coming to Egypt and by the Total tourism revenue in Egypt (value in billion dollars). Also, we analyze the relative distribution of tourists coming to Egypt and their distribution according to places of visit.

Then and according to Table 1, there are many recreational tourist places in Egypt, as Egypt enjoys an excellent location, so it contains a lot of tourist cities that tourists visit and one of the most important recreational tourism places in Egypt is Luxor (22.6\%), Giza Pyramids (17.8\%), Aswan (14.9\%), Cairo (11.6\%) and other places (31.3\%).

Based on Table 2, Western Europe is the largest source of tourists to Egypt, followed by Eastern Europe, then the Middle East and Africa, and the United States and other nationalities remain at the bottom of that list in terms of the number of arrivals to Egypt. In the past, Egypt depended on the cultural and archaeological heritage to attract tourists, but since the remarkable development in the sites of tourist sites in the Red Sea and South Sinai, entertainment tourism has become the main reason for the visit.

With regard to the development of the number of tourists in Egypt, we note, according to the information in Table 3, that the number of tourists was constantly increasing from the year 2004 (8.1 million tourists) to the year 2010 (14.7 million tourists). However, after the Egyptian revolution and the multiplicity of political and security crises in Egypt, especially terrorist attacks as well as the global financial crisis, the number of tourists in Egypt began to decrease, reaching in the year 2016 to 5.6 million tourists. However, with the Egyptian internal and external policies pursued, especially at the security, political, economic, and social levels, Egypt was able to retrieve the number of tourists to reach 11.3 million tourists in 2018.

About the tourism receipts in Egypt, we note, according to the information in Table 4, that the level of revenue has been on the rise from 2004 ( $\$ 4.6$ billion) to 2009 (\$ 11.6 billion). But after the Egyptian revolution and the multiplicity of political and security crises in Egypt, especially terrorist attacks, as well as the global financial crisis, revenues in Egypt began to decrease, reaching in the year 2015 to $\$ 3.8$ billion. However, with the Egyptian internal and external policies pursued, especially at the security, political, economic, and social levels, Egypt was able to recover tourism revenues to reach $\$ 12.6$ billion in 2018 .

Table (1): Relative distribution of tourists according to places of visit during 2013

\begin{tabular}{|c|c|}
\hline Area & Percentage \\
\hline Luxor & 22.6 \\
\hline Giza Pyramids & 17.8 \\
\hline Aswan & 14.9 \\
\hline Cairo & 11.6 \\
\hline Egyptian Museum & 8.5 \\
\hline Alexandria & 6.9 \\
\hline South Sinai & 4.5 \\
\hline Coptic Museum & 3.1 \\
\hline Others & 8.3 \\
\hline
\end{tabular}

Source: Egyptian Ministry of Tourism and Antiquities (2017)

Table (2): The relative distribution of tourists coming to Egypt

\begin{tabular}{|c|c|c|c|c|c|c|c|}
\hline \multicolumn{2}{|c|}{ Year } & $\mathbf{2 0 0 8}$ & $\mathbf{2 0 0 9}$ & $\mathbf{2 0 1 0}$ & $\mathbf{2 0 1 1}$ & $\mathbf{2 0 1 2}$ & $\mathbf{2 0 1 3}$ \\
\hline Percentage & Europe & 75 & 75.1 & 75.9 & 73.2 & 73 & 73.7 \\
\cline { 2 - 8 } & $\begin{array}{c}\text { Middle } \\
\text { East }\end{array}$ & 13.1 & 12.5 & 12 & 15.4 & 17 & 15.8 \\
\cline { 2 - 8 } & Africa & 3.1 & 3.6 & 3.3 & 4.4 & 3.7 & 4.2 \\
\cline { 2 - 8 } & Asia & 4.8 & 4.5 & 4.8 & 3.9 & 3.6 & 3.5 \\
\hline
\end{tabular}

Source: Egyptian Ministry of Tourism and Antiquities (2017) 
Table (3): Total number of tourists coming to Egypt (value in million)

\begin{tabular}{|c|c|}
\hline Year & The total number of tourists (value in a million" \\
\hline 2004 & 8.1 \\
\hline 2005 & 8.6 \\
\hline 2006 & 9.1 \\
\hline 2007 & 11.1 \\
\hline 2008 & 12.8 \\
\hline 2009 & 12.5 \\
\hline 2010 & 14.7 \\
\hline 2011 & 9.8 \\
\hline 2012 & 11.5 \\
\hline 2013 & 9.5 \\
\hline 2014 & 9.9 \\
\hline 2015 & 9.3 \\
\hline 2016 & 5.4 \\
\hline 2017 & 8.3 \\
\hline 2018 & 11.3 \\
\hline
\end{tabular}

Source: World Tourism Organization (2019)

Table (4): Total tourism revenue in Egypt (value in billion dollars)

\begin{tabular}{|c|c|}
\hline Year & $\begin{array}{c}\text { Total tourism revenue in Egypt (value in billion } \\
\text { dollars) }\end{array}$ \\
\hline 2004 & 6.4 \\
\hline 2005 & 7.2 \\
\hline 2006 & 8.2 \\
\hline 2007 & 10.8 \\
\hline 2008 & 10.5 \\
\hline 2009 & 11.6 \\
\hline 2010 & 10.6 \\
\hline 2011 & 9.4 \\
\hline 2012 & 9.8 \\
\hline 2013 & 5.1 \\
\hline 2014 & 7.4 \\
\hline 2015 & 3.8 \\
\hline 2016 & 4.4 \\
\hline 2017 & 9.8 \\
\hline 2018 & 12.6 \\
\hline
\end{tabular}

Source: World Tourism Organization (2019)

\section{Conclusion}

If tourism is prosperous in a country, this will make this country the beginning of progress in various fields, and even the people within it will enjoy the luxury and meet all the requirements that are right for the state, then there can be rights due to them, but they were not able to fulfill them due to the bad economy in them.

But as the economy improves, it will be easy to meet all the needs of all members of the state, and we find that the many types of tourism make tourists flock to length for enjoyment, treatment and study, there is not one type of tourism, but there are several important types, all aiming for advancement And the development of the country.

In our paper, we find that tourism is of great importance in solving many of the problems facing countries, and the most important of these are the economic problems that make citizens confused about them, and here we will know these problems: and we find that the main reason is unemployment, so there is no country in which there are no individuals that do not They work, and the reason is that there is no place to work, so they are called unemployment, that is, they do not work and therefore they do not have a steady income in their lives, so they resort to becoming dependent on society and this in turn causes great harm to society, so we find that the presence of tourism makes a great need For large numbers of young people to work to meet the demands of foreigners in Guet tourism, so there will be work available at this time and there is no unemployment in the society. 
The national income of the country increases a lot, so the entry of any foreign currency to any country makes its position important between the country, so its income increases clearly and this affects its wealth and all the good it has on everyone, if the state is rich then we will find that this affects all people, If they are poor, this also affects them and makes them at a low level. The money that enters these countries through tourism, is to benefit from them in very important areas, including agriculture, which is developing a lot to export crops that help increase the income of countries. Because of the excess income from tourism, there will be a noticeable development in any institution in the state, and this is one of the most successful in the country. We find that there is also a great reason for the importance of tourism, which is the dealings of countries together, so we find that because of tourism there is the ability to trade between countries, so relationships arise because of this trade that makes there noticeable cooperation between countries and this in turn makes there prosperity and growth in the economy like no other.

Acknowledgments: The authors are grateful to the Editor in Chief and the anonymous referees of the journal for their extremely useful suggestions to ameliorate the quality of this study.

Declaration of Conflicts of Interest: The authors proclaimed that they do not have any possible conflicts of interest regarding the paper, production, and publication of this study.

Funding: The authors obtained no financial funding for the paper, production, and publication of this study.

\section{References:}

[1] Avraham, E. (2016). "Destination marketing and image repair during tourism crises: The case of Egypt", Journal of Hospitality and Tourism Management. 28(3): 41-48, https://doi.org/10.1016/j.jhtm.2016.04.004.

[2] Aziz, H. (1995). "Understanding attacks on tourists in Egypt". Tourism Management. 16(2): 91-95, https://doi.org/10.1016/0261-5177(94)00016-4.

[3] Brida, J.G., Gomez, D.M. \& Segarra, V. (2020). "On the empirical relationship between tourism and economic growth". Tourism Management. 81(1): 104131, https://doi.org/10.1016/j.tourman.2020.104131.

[4] Dana, R. (2017). Egypt's tourism industry suffers a critical blow. DW.

[5] Drakos, K. \& Kutan, A.M. (2003). “Regional Effects of Terrorism on Tourism in Three Mediterranean Countries”. Journal of Conflict Resolution. 47(5): 621-641.

[6] El Gohary, H. (2012). "Factors affecting E-Marketing adoption and implementation in tourism firms: An empirical investigation of Egyptian small tourism organizations". Tourism Management. 33(5): 1256-1269, https://doi.org/10.1016/j.tourman.2011.10.013.

[7] Farouk, D. (2014). "Egypt tourist numbers decline 20.5 pct in June year-on-year". Ahram Online.

[8] Haiying, Z. (2019). "Egypt Tourism and Its Importance in Sustainable Development Goals", Proceedings of the Third International Conference on Social Transformation, Community and Sustainable Development (ICSTCSD 2019), https://doi.org/10.2991/icstcsd-19.2020.4.

[9] Helen, C. (2017). Why UK Tourists Should Consider Returning to Egypt on Holiday. The Independent.

[10] Ragab, A. (2014). Recent development of TSAin Egypt (pdf). Fourteenth Meeting of the Committee of Statistics and Tourism Satellite Account (TSA).

[11] Salah Eli Din, S.M. (2020). "Current Status and Prospects for Development of International Tourism in the Arab Republic of Egypt", Proceedings of the International Scientific Conference "Far East Con" (ISCFEC 2020), https://doi.org/10.2991/aebmr.k.200312.333.

[12] Shaalan, I.M. (2005). "Sustainable tourism development in the Red Sea of Egypt threats and opportunities". Journal of Cleaner Production. 13(2): 83-87, https://doi.org/10.1016/j.jclepro.2003.12.012.

[13] Smith, M. (2014). Egypt tourist numbers to rise 5-10 pct in 2014 - minister. Reuters.

[14] Smith, M. (2014). www.dailymail.co.uk/travel/travel_news/article-2738446/ Egypt-hit-95-decline-tourism-revenuewestern-travel-warnings-social-unrest-blame.html - minister. Daily Mail. 